ON THE TRAIL 
This page intentionally left blank 


\title{
SILAS CHAMBERLIN
}

\author{
On the Trail
}

A History of American Hiking

\author{
Yale \\ UNIVERSITY \\ PRESS
}

NEW HAVEN AND LONDON 
Published with assistance from the foundation established in memory of Philip Hamilton McMillan of the Class of 1894, Yale College.

Copyright (c) 2016 by Silas Chamberlin.

All rights reserved.

This book may not be reproduced, in whole or in part, including illustrations, in any form (beyond that copying permitted by Sections 107 and 108 of the U.S. Copyright Law and except by reviewers for the public press), without written permission from the publishers.

Yale University Press books may be purchased in quantity for educational, business, or promotional use. For information, please e-mail sales.press@yale.edu (U.S. office) or sales@yaleup.co.uk (U.K. office).

Set in New Aster type by IDS Infotech, Ltd.

Printed in the United States of America.

Library of Congress Control Number: 2016936121

ISBN 978-0-300-21911-1 (hardcover)

A catalogue record for this book is available from the British Library.

This paper meets the requirements of ANSI/NISO Z39.48-1992

(Permanence of Paper).

10987654321 
For my parents, Bob and Sue, my wife, Amanda, and my daughter, Lily 
This page intentionally left blank 